\title{
Aspectos político-econômicos da Província de São Paulo no Primeiro Reinado
}

\author{
Political and economic aspects of São Paulo in the \\ First Reign
}

\author{
Carlos Eduardo França de Oliveira* \\ http://orcid.org/0000-0001-5526-7966
}

\begin{abstract}
Resumo
Inscrito no campo da história política sobre o Império, o presente artigo objetiva analisar a projeção de políticos paulistas nas esferas provincial e nacional durante o Primeiro Reinado, movimento esse que esteve articulado a pelo menos dos processos interligados. De um lado, o da progressiva inserção da província de São Paulo na economia do centro-sul do Império, o que ampliou as possibilidades de negócios para setores proprietários que vinham amealhando riquezas desde fins do século XVIII. De outro, o da participação dos paulistas na construção do projeto, ainda que não consensual, de Estado nacional monárquico com sede no Rio de Janeiro. A ideia é mapear as regiões da província bem como seus respectivos representantes políticos, buscando estabelecer possíveis laços de parentesco, negócios e atuação na cena pública entre esses homens. Procura-se, assim, contribuir para o entendimento sobre o papel de São Paulo na estruturação do Primeiro Reinado.
\end{abstract}

Palavras-chave: Império; província de São Paulo; história política; século XIX.

\begin{abstract}
Inscribed in the of political history field about the Brazilian Empire, this article aims to assay the paulistas's politicians projection in the provincial and national spheres under the First Reign, a processes articulated with two interconnected movements. On the one hand, either the progressive insertion of the province of São Paulo into the economy of the centro-sul of the Bazilian Empire, or that has expanded as business opportunities for the vineyard sectors enhance the riches at the end of the century. On the other, the participation of the paulistas in the construction of a project, although not consensual, of constitutional monarchy based in Rio de Janeiro. The idea is to map the regions of the province, as well as their political representatives, looking for possible risks of kinship, business and public performance among
\end{abstract}

*Doutor em História Social pela Universidade de São Paulo. Professor adjunto do Departamento de História da Universidade Estadual do Centro-Oeste, campus Irati. E-mail: carlosoliveira@unicentro.br 
these men. The article seeks to, that is, to contribute to the understanding of São Paulo's role in the First Reign.

Keywords: Empire of Brazil; province of São Paulo; political history; nineteenth century.

\section{A província de São Paulo entre percursos historiográficos}

No início do Oitocentos, o adensamento do movimento de mercantilização da produção e da concentração fundiária no centro-sul, aliado às disputas pelo controle do mercado fluminense, do comércio de cabotagem e das atividades importadoras e exportadoras, impulsionou embates intensos entre negociantes radicados na Corte e no Reino de Portugal, mercadores ingleses, proprietários do sul de Minas, São Paulo e do norte fluminense (Recôncavo e Campos de Goitacases). ${ }^{1}$ Esses enfrentamentos ganham amplitude quando cotejados à bibliografia mais recente, a qual vem mostrando que em São Paulo delineava-se uma economia dinâmica, com possibilidades variadas de produção e mercado, que era atrativa para setores diversos da população, situação distante do perfil decadentista replicado pelos estudos tradicionais sobre a província na primeira metade do século XIX. ${ }^{2}$

Os textos mais conhecidos sobre a história de São Paulo não se detiveram suficientemente nos processos inseridos entre dois supostos marcos - 0 bandeirismo e o advento do café -, ora enfatizando a proeminência dos bandeirantes na ocupação do território e na descoberta das minas, ora afirmando que o dinamismo socioeconômico de São Paulo se cristalizou a partir de 1850, com o desenvolvimento da lavoura cafeeira. A maneira grandiloquente como foram tratados esses dois temas, aliada a uma suposta escassez de fontes referentes ao desenvolvimento socioeconômico paulista no período anterior a

\footnotetext{
${ }^{1}$ OLIVEIRA, Cecilia Helena L. de Salles. A astúcia liberal. Relações de Mercado e Projetos Políticos no Rio de Janeiro (1820-1824). São Paulo: Ícone e Edusf, 1999, p.80.

${ }^{2}$ Segundo parte da bibliografia consagrada, São Paulo passou por um sensível período de decadência entre o término do movimento bandeirista e meados do século XIX, momento em que houve um incremento econômico proporcionado pela lavoura cafeeira exportadora. Cf. CANABRAVA, Alice. "Uma economia de decadência: os níveis de riqueza na Capitania de São Paulo, 1765/1767". In Revista Brasileira de Economia. Rio de Janeiro, v. 26, n. 4, p. 95-123, out.-dez. 1972; ELLIS JR., Alfredo. A economia paulista no século XVIII: ciclo do muar, ciclo do açúcar. São Paulo: Academia Paulista de Letras, 1979; PRADO, Paulo. Paulística etc. São Paulo: Companhia das Letras, 2001; PRADO JR., Caio. Formação do Brasil Contemporâneo. $34^{a}$ edição. São Paulo: Brasiliense, 1999; LYRA, Maria de Lourdes Viana. Dízimos Reais na Capitania de São Paulo. Contribuição à História Tributária do Brasil Colonial (1640-1750). 1970. Dissertação (Mestrado em História) - Faculdade de Filosofia, Letras e Ciências Humanas, Universidade de São Paulo, São Paulo, 1970.
} 
1872, ano do primeiro censo nacional, fez com que grande parte da bibliografia considerasse esse período "intermediário" como de pouca expressividade, portador de uma estagnação socioeconômica que só seria superada com a consolidação do "ouro verde". ${ }^{3}$

Trabalhos produzidos a partir da década de 1970 questionaram diretamente a insuficiência do paradigma da decadência paulistana e, em termos gerais, paulista. ${ }^{4}$ Ao discutir o grande crescimento demográfico ocorrido em São Paulo entre 1690 e 1765, Maria Luiza Marcílio notou que nesse período houve um aumento nas atividades agrícolas da capitania, seja em decorrência do acréscimo populacional ocasionado pelo advento da exploração do ouro, seja pela transplantação da sede da América portuguesa de Salvador para o Rio de Janeiro. No clássico A Lavoura Canavieira em São Paulo, Maria Thereza Petrone demonstra que o sucesso das lavouras de café a partir de 1850 só foi possível devido à infraestrutura - comercial, financeira e de transportes - implementada pela cultura canavieira durante o último quartel do século XVIII e a primeira metade do século XIX. Tal infraestrutura, contudo, só pode ser concretizada na medida em que a economia de São Paulo sofreu gradativamente uma alteração estrutural, ou seja, passou de uma configuração mais regional e voltada para o mercado interno para outra assentada na grande produção exportadora e escravista. Petrone nota que esses dois processos, ocorridos de forma simultânea e articulada, resultaram da ação dos políticos da capitania como idealizadores de políticas públicas voltadas para sua viabilização. ${ }^{5}$

Mais recentemente, Ana Paula Medicci observou que o dinamismo econômico de São Paulo ao longo do século XVIII - oriundo, sobretudo, da produção e do comércio de produtos agrícolas -, além de colocar em dúvida a noção de declínio, permite questionar o porquê da construção dessa ideia. ${ }^{6}$

\footnotetext{
${ }^{3}$ LUNA, Francisco Vidal; KLEIN, Herbert S. Evolução da Sociedade e Economia Escravista de São Paulo, de 1750 a 1850. São Paulo: EDUSP, 2006. p. 15-24.

${ }^{4}$ ABUD, Kátia Maria. Autoridade e riqueza. Contribuição para o estudo da sociedade paulistana na segunda metade do século XVIII. 1978. Dissertação (Mestrado em História Social) - Faculdade de Filosofia, Letras e Ciências Humanas, Universidade de São Paulo, São Paulo, 1978; KUZNESOF, Elizabeth Anne. "The role of merchants in the economic development of São Paulo: 1765-1850". In Hispanic American Historical Review, v. 60, p. 571-592, nov. 1980; MARCÍlIO, Maria Luiza. Crescimento demográfico e evolução agrária paulista. 17001836. São Paulo: Hucitec/Edusp, 2000; RABELLO, Elizabeth Darwiche. As elites na sociedade paulista da segunda metade do século XVIII. São Paulo: Safady, 1980.

${ }^{5}$ PETRONE, Maria Thereza Schorer. A lavoura canavieira em São Paulo. Expansão e declínio (1765-1851). São Paulo, Difusão Europeia do Livro, 1968.

${ }^{6}$ MEDICCI, Ana Paula. Entre a "decadência" e o "florescimento": capitania de São Paulo na interpretação de memorialistas e autoridades públicas (1782/1822). 2005. Dissertação (Mestrado em História) - Faculdade de Filosofia, Letras e Ciências Humanas, Universidade de São Paulo, São Paulo, 2005.
} 
A autora assinala como o discurso da decadência produzido por autoridades públicas entre 1782 e 1822, apropriado posteriormente por parcela da bibliografia como indício da fragilidade da economia paulista, esteve intimamente associado aos interesses desses funcionários, preocupados em legitimar sua intervenção política diante de situações forjadas por sua própria retórica, procedimento esse observado por Milena Maranho já para o século XVII. ${ }^{7}$ Cabe ressaltar, ainda, as pesquisas que vêm desvendando os laços entre negócios e política na capitania e depois província de São Paulo, especialmente ao mostrar a participação dos comerciantes na economia paulista, bem como a inserção desses homens nas esferas oficiais de poder. ${ }^{8}$

Se a constatação da diversidade de situações regionais, atividades produtivas e relações de trabalho tem gerado pesquisas que, em conjunto, evidenciam a impossibilidade de tratarmos a São Paulo oitocentista de forma homogênea no campo econômico ${ }^{9}$, fenômeno semelhante parece estar ocorrendo, embora com outros horizontes de preocupação, com relação à política.

Nas últimas décadas, historiadores têm apontado para o fato de que a formação do Estado nacional brasileiro inscreve-se num movimento de ampla complexidade desencadeado por sucessivas transformações precipitadas na América portuguesa desde meados do século XVIII, quando a política levada adiante por Lisboa, com vistas a reestruturar as bases do Império luso, pretendeu remodelar a relação entre metrópole e colônias. De um lado buscou-se modernizar o aparelho estatal administrativo e tributário, fomentar as manufaturas em Portugal e reforçar o monopólio comercial. De outro,

\footnotetext{
${ }^{7}$ MARANHO, Milena Fernandes. A opulência relativizada: significados econômicos e sociais dos níveis de vida dos habitantes da região do Planalto de Piratininga (1648-1682). Bauru: Edusc, 2000.

${ }^{8}$ ARAÚJO, Maria Lucília Viveiros. Os caminhos da riqueza dos paulistanos na primeira metade do oitocentos. São Paulo: Hucitec/Fapesp, 2006; BORREGO, Maria Aparecida de Menezes. A teia mercantil: negócios e poderes em São Paulo colonial (1711-1765). São Paulo: Alameda/Fapesp, 2010; MATTOS, Renato de. Política, administração e negócios: a capitania de São Paulo e sua inserção nas relações mercantis do Império Português (1788-1808). 2009. Dissertação (Mestrado em História) - Faculdade de Filosofia, Letras e Ciências Humanas, Universidade de São Paulo, São Paulo, 2009; MEDICCI, Ana Paula. Administrando conflitos: o exercício do poder e os interesses mercantis na capitania/província de São Paulo (1765-1822). 2010. Tese (Doutorado em História) - Faculdade de Filosofia, Letras e Ciências Humanas, Universidade de São Paulo, São Paulo, 2010; MONT SERRATH, Pablo Oller Mont. Dilemas e conflitos na São Paulo restaurada: formação e consolidação da agricultura exportadora (1765-1802). 2007. Dissertação (Mestrado em História) - Faculdade de Filosofia, Letras e Ciências Humanas, Universidade de São Paulo, São Paulo, 2007; PUNTSCHART, William. Negócios e negociantes paulistas (1808-1822). 1998. Tese (Doutorado em História) - Faculdade de Filosofia, Letras e Ciências Humanas, Universidade de São Paulo, São Paulo, 1998.

${ }^{9} \mathrm{GODOY}$, Marcelo Magalhães. Intrépidos viajantes e a construção do espaço: uma proposta de regionalização para as Minas Gerais do século XIX. Belo Horizonte: UFMG/Cedeplar, 1996; PAIVA, Clotilde Andrade de. População e economia nas Minas Gerais do século XIX. 1996. Tese (Doutorado em História) - Faculdade de Filosofia, Letras e Ciências Humanas, Universidade de São Paulo, São Paulo, 1996.
} 
contraditoriamente, setores proprietários da América portuguesa passaram a ter maior acesso à administração colonial, valendo-se dessa condição para amealharem fortunas, muitas vezes à revelia da metrópole. Isso tudo faz mais sentido quando lembramos que tanto a separação entre Portugal e Brasil quanto as iniciativas referentes à criação de um Estado autônomo e sob o governo de d. Pedro só obtiveram sucesso devido ao amplo apoio franqueado por grupos que vinham ascendendo economicamente desde o final do setecentos, especialmente no centro-sul da América portuguesa, em virtude da dinamização das atividades econômicas do Rio de Janeiro, capital do ViceReino do Brasil desde 1763 e um dos centros comerciais de maior significância dentro dos domínios lusos. ${ }^{10}$

O que particularmente interessa aqui é o fato de que esse enraizamento de interesses em terras americanas foi um dos vetores centrais não apenas no encaminhamento das relações entre portugueses da Europa e América - e, posteriormente, na instalação das bases do futuro Império brasileiro -, mas particularmente na dinâmica da esfera pública do eixo centro-sul da América portuguesa. ${ }^{11} \mathrm{~A}$ incerteza dos primeiros anos do século XIX fez com que atividades como o tráfico negreiro, o contrabando, o comércio de abastecimento e os contratos de arrematação passassem a congregar grupos diversos que, de acordo com a conjuntura vigente, aproximavam-se ou entravam em conflito para manter sua influência.

Todos eles - comerciantes de grosso trato do Rio de Janeiro, negociantes portugueses vinculados à importação, produtores associados ao comércio de cabotagem, setores representantes do ramo de abastecimento, agricultores, entre outros - divisaram na acomodação da Coroa no Rio de Janeiro a possibilidade de se instalarem tanto nos circuitos de mercado como no aparelho administrativo da monarquia portuguesa em reformulação. Assim, longe de constituir uma associação coagida de forças, tal movimento contou com participação efetiva dos portugueses da América na execução de redefinição da monarquia lusa. ${ }^{12}$

\footnotetext{
${ }^{10}$ OLIVEIRA, Cecilia Helena L. de Salles. "Repercussões da revolução: delineamento do império do Brasil, 1808/1831”. In GRINBERG, Keila; SALLES, Ricardo (Orgs.). O Brasil Imperial. Rio de Janeiro: Civilização Brasileira, 2009, p.17-54.

${ }^{11}$ LYRA, Maria de Lourdes Viana. A utopia do poderoso império: Portugal e Brasil: bastidores da política, 17981822. Rio de Janeiro: Sette Letras, 1994.

${ }^{12}$ FRAGOSO, João Luiz Ribeiro. Homens de grossa aventura: acumulação e hierarquia na praça mercantil do Rio de Janeiro (1790-1830). Rio de Janeiro: Arquivo Nacional, 1992.
} 
Peça dessa complexa engrenagem política e econômica, São Paulo vivenciou uma paulatina redefinição de posições dentro do centro-sul e, mais especificamente, na relação que estabeleciam com o Rio de Janeiro. Um dos aspectos que mais chama atenção desse cenário é o de que, entre fins do século XVIII e início do XIX, tento em vista a praça comercial do Rio de Janeiro, famílias paulistas e mineiras, muitas delas oriundas das atividades mineradoras, concentraram seus esforços na produção e circulação de gêneros de exportação e primeira necessidade e no tráfico de escravos, empreitada que envolvia o sul de Minas (especialmente a Comarca do Rio das Mortes), áreas do vale do Paraíba, além da própria capital. Por meio de aquisição de sesmarias, processo que se intensifica com a chegada da Corte, passam a ocupar extensas faixas de terras e a participar da fundação de vilas e freguesias, da abertura de caminhos, e da expulsão de povos indígenas residentes nas áreas destinadas à lavoura, na região configurada a oeste pelo Rio Preto e a norte e sul pelos "caminhos do ouro", envolvendo parte do vale do Paraíba Paulista e o fluminense. ${ }^{13}$

Tal integração não era apenas econômica. Paulistas estavam próximos como nunca do centro decisório da política, e por isso viram-se diante da possibilidade de passar a gerir a coisa pública. Afinal, a instalação da Corte também significava uma nova estrutura de destinação de receitas fiscais, empregos, cargos a serem ocupados e outras questões de ordem prática. Com isso a Corte centralizou o aparelho administrativo em torno do Rio de Janeiro assim como criou uma burocracia capaz de proporcionar um movimento mais amplo de articulação inter-regional, a fim de viabilizar a permanência da cabeça da monarquia no centro-sul brasileiro.

Mais do que cooptar as lideranças regionais para o fomento de uma infraestrutura (comercial, financeira e de transportes) que satisfizesse as demandas da Corte, processo esse exteriorizado pela criação de novos impostos, tratados de comércio e vias de comunicação, a burocracia implantada durante o período joanino instaurou uma estrutura política, ao mesmo tempo prática e teórica, que conferiu soberania ao Rio de Janeiro diante das demais partes da América portuguesa. ${ }^{14}$ Se assumirmos que, durante o período colonial, o relacionamento direto entre as capitanias e a metrópole foi prática comum,

\footnotetext{
${ }^{13}$ BITTENCOURT, Vera Lúcia Nagib. De alteza real a imperador: o governo do Príncipe D. Pedro, de abril de 1821 a outubro de 1822. 2007. Tese (Doutorado em História) - Faculdade de Filosofia, Letras e Ciências Humanas, Universidade de São Paulo, São Paulo, 2007, p.136.

${ }^{14}$ SOUZA, Iara Liz Carvalho. A pátria coroada: o Brasil como um corpo político autônomo, 1780-1831. São Paulo: Unesp, 1999.
} 
a instauração de um aparelho administrativo que garantisse a legitimidade do Rio de Janeiro como centro do governo esteve estreitamente atrelada à criação de um aparato burocrático com lastro nas demais regiões da América portuguesa. A aproximação com os setores da antiga colônia foi, portanto, um elemento chave no aparelhamento e na viabilização de um novo Estado, notadamente no estabelecimento de uma infraestrutura material que permitisse a acomodação dessa nova realidade. ${ }^{15}$

Os setores diretamente beneficiados com a chegada da família real sobretudo membros da burguesia portuguesa e nobres emigrados para o Rio de Janeiro, bem como ricos negociantes e proprietários fluminenses - estavam originalmente associados ao projeto do Conde de Linhares, o qual buscava reformular o Império português a partir do reconhecimento do Reino do Brasil como peça chave na estrutura imperial lusa. A ideia da formação de um Império português renovado com sede no Rio de Janeiro compactuava com o entendimento de que o imenso território colonial - dotado de regiões distintas economicamente, repleto de recursos naturais e com uma população livre em crescimento - guardava as condições necessárias para a produção de riquezas e para o delineamento de uma entidade política autônoma, cujo sucesso poderia equipará-lo às nações ditas civilizadas.

Mais tarde, quando o movimento revolucionário do Porto já encontrava desdobramentos em terras brasileiras, esses homens, diante da impossibilidade de conciliar os interesses dos portugueses dos dois lados do Atlântico, participaram diretamente na separação de Portugal, defendendo um Estado monárquico centralizado, unitário, de dimensões imperiais, em que a política local estaria subordinada ao governo central, reafirmando-se aí a proeminência do Rio de Janeiro como centro do Império, e em que a Coroa gozaria de um papel de destaque na condução da máquina pública, aspirações essas que ganharam concretude na Carta de $1824 .{ }^{16}$

Essas figuras, todavia, não estavam a sós, e aqui reside um ponto central para este estudo. Desde os primeiros decênios do século XIX assistiram ao advento de múltiplos interlocutores no campo da política, uma das consequências da luta pela conquista de mercados, terras, capital e poder dentro do panorama acima descrito. Dito isso, é de se lembrar que a participação de

${ }^{15}$ LENHARO, Alcir. As tropas da moderação: o abastecimento da Corte na formação política do Brasil: 18081842. Rio de Janeiro: Biblioteca Carioca, 1993.

${ }^{16}$ JANCSÓ, István. “A construção dos Estados Nacionais na América Latina. Apontamentos para o estudo do Império como projeto”. In SZMERECSÁNYI, Tamás; LAPA, José Roberto do Amaral (Orgs). História econômica da Independência e do Império. São Paulo: Hucitec/FAPESP, 1996. p. 3-26. 
negociantes, agricultores, militares e burocratas na base de sustentação do governo joanino e, posteriormente, do Primeiro Reinado, ainda que variada, não abrangeu todos os setores proprietários do centro-sul beneficiados com a instalação da Corte no Rio de Janeiro. A projeção política da maior parte da classe proprietária, sobretudo de pequenos e médios produtores, ainda se encontrava atada à esfera local, quadro que não se alterou substancialmente com a instauração do Império brasileiro, mas que foi mudando ao longo das décadas de 1830. Alguns desses homens e suas respectivas regiões de origem e atuação economia e/ou política serão apresentados agora.

\section{A província de São Paulo na década de 1820: laços familiares, políticos e de negócios}

Na primeira metade do século XIX, a cidade de São Paulo constituía o ponto de referência para a província como um todo. ${ }^{17}$ Centro político-administrativo e militar, sede do bispado local e o principal elo político com a Corte, sua localização estratégica lhe rendera muito cedo a condição de entroncamento viário para as principais regiões da província: para o norte, seguindo pelos sertões do Camanducaia e do Sapucaí, atingia-se Juqueri, Atibaia, Bragança e o sul de Minas; para norte/nordeste, passando por Jundiaí, Campinas, Moji-Mirim e o sertão do Rio Pardo, chegava-se a Minas Gerais e Mato Grosso; para leste estendia-se o vale do Paraíba, que fazia fronteira com o Rio de Janeiro; para o noroeste, o viajante encontrava Itu e Porto Feliz e, mais a oeste, trilharia por Sorocaba, Faxina, até chegar nos campos de Curitiba; por fim, era possível seguir para o sul, rota que desembocava no litoral e no porto de Santos. ${ }^{18}$ Por isso mesmo o centro administrativo paulista era local de passagem de viajantes e tropas que escoavam a produção do planalto, impondo-se como espaço privilegiado de negócios da província.

São Paulo não era, em si, um núcleo produtivo de grande importância. ${ }^{19}$ Além do chá, a principal cultura agrícola da cidade, esta produzia em pequena escala aguardente, arroz, farinha de mandioca, feijão, milho, amendoim, fumo e algodão, além de contar com criações de porcos e de algum gado cavalar, muar e vacum. Havia também a confecção de telhas e couros. As atividades urbanas eram o cerne da vida econômica paulistana, que contava com

\footnotetext{
${ }^{17}$ MOURA, Denise A. Soares de. Sociedade movediça, economia, cultura e relações sociais em São Paulo - 1808-1850. São Paulo: Ed. Unesp, 2006.

${ }^{18}$ PRADO JR., Caio. Evolução política do Brasil e outros estudos. São Paulo: Brasiliense, 1972.

${ }^{19}$ MORSE, Richard M. Formação histórica de São Paulo. São Paulo: Difusão Europeia do Livro, 1970.
} 
alfaiates, carpinteiros, sapateiros, ferreiros, caixeiros negociantes, pescadores, seleiros, pedreiros, costureiras, marceneiros, serradores, tanoeiros, oleiros, barbeiros, dentre outros profissionais. No campo da cultura, São Paulo dava os primeiros passos para se aproximar de outras capitais do Império, sendo fundamentais nesse quesito o advento do Gabinete Literário (1825) - primeira biblioteca pública da cidade -, do Curso Jurídico (1827), da primeira tipografia da província (1827), da Sociedade Filomática (1830) e da Sociedade Harmonia Paulistana (1832). ${ }^{20}$

São Paulo, porque capital, era por excelência o palco da política paulista, seja por abrigar as mais altas esferas do poder institucionalizado, seja por contar com um espaço extraoficial de debate mais dinâmico, que tinha como combustível a única tipografia em solo paulista até meados dos anos 1830 . Fato curioso, todavia, é o de que, durante o Primeiro Reinado e o início da Regência, a cidade de São Paulo foi, por assim dizer, menos o reduto de nomes consagrados do que propriamente um centro de articulação política onde setores de diferentes partes da província se faziam presentes e lutavam pelo poder. É evidente que entre os paulistanos havia nomes de certa projeção, sobretudo no seio dos autointitulados liberais, e que as corridas eleitorais da época revelam um esforço no sentido de promover políticos de raízes locais, em sua maioria homens ligados às atividades da administração municipal, como vereadores, juízes de paz, oficiais de milícias e, posteriormente, das guardas nacionais. Mas o diferencial da política da cidade estava justamente na atuação de homens como o baiano José da Costa Carvalho, que se fixou em São Paulo ainda jovem e ali costurou laços de amizade, família e negócios, além de bancar a fundação do primeiro jornal impresso da província: 0 Farol Paulistano. ${ }^{21}$ Por meio do matrimônio com Genebra de Barros Leite, viúva

\footnotetext{
${ }^{20}$ BRUNO, Ernani da Silva. História e tradições da cidade de São Paulo. Rio de Janeiro: José Olympio, 1953; QUEIRÓZ, Suely Robles Reis de. São Paulo. Madrid: MAPFRE, 1992.

${ }^{21}$ José da Costa Carvalho (1796-1860), Barão, Visconde e depois Marquês de Monte Alegre, era natural da Freguesia da Nossa Senhora da Penha, situada nos arredores de Salvador. Filho de pai homônimo e de Ignez Maria Piedade Costa, estudou Leis na Universidade de Coimbra, onde se formou em 1819. De volta ao Brasil, iniciou sua carreira pública pela magistratura, ocupando os cargos de juiz de fora e ouvidor da cidade de São Paulo, entre 1821 e 1822, período em que se casou com Genebra de Barros Leite, viúva do Brigadeiro Luis Antonio de Sousa Queiróz. Sua carreira política iniciou-se quando foi eleito ao cargo de deputado pela Bahia para a Assembleia Constituinte de 1823. Ao longo do Primeiro Reinado, foi deputado pela Bahia nas duas primeiras Legislaturas. Durante esse período, foi presidente da Câmara dos Deputados (de 5 de maio a 3 de julho de 1828; de 4 de maio a 3 de julho de 1830; de 3 de agosto de 1830 a 4 de maio de 1831); vice-presidente da Câmara dos Deputados (de 4 de maio de 1827 a 5 de maio de 1828); e Primeiro Suplente da Mesa Diretora (de 2 de agosto de 1828 a 4 de maio de 1829). Ainda durante o Primeiro Reinado, Costa Carvalho foi membro regular dos Conselhos da Presidência e Geral de São Paulo. Com a Abdicação, tornou-se membro da Regência Trina Permanente, em 17 de junho de 1831.
} 
do abastado brigadeiro Luis Antônio, tornou-se proprietário de fazendas na área de Itu e São Carlos, de antiga propriedade do falecido. O casamento proporcionou-lhe contato com nomes influentes da política paulista, como Feijó, Paula Sousa e Vergueiro, com os quais se aliaria durante o Primeiro Reinado. Na capital da província, Costa Carvalho foi ouvidor, juiz de fora e membro dos Conselhos Geral e da Presidência. ${ }^{22}$ Nas duas primeiras legislaturas do Império, optou por tomar assento na Câmara dos Deputados por sua província natal, prática comum adotada pelos políticos da época para franquear espaço para aliados.

Dada sua importância administrativa, militar e religiosa, não é de estranhar que os principais nomes saídos da capital paulista fossem funcionários públicos, magistrados - alguns deles inclusive recém-formados pelo Curso Jurídico -, militares e eclesiásticos. Não é surpresa, também, que ali circulassem homens próximos a D. Pedro, em virtude dos cargos de nomeação exclusiva do Executivo do Rio de Janeiro, da teia administrativa que enredava províncias e o centro do Império, e da participação da capital paulista no projeto de monarquia constitucional sediada na Corte fluminense. Assim como outras capitais do Império, a exemplo de Ouro Preto, São Paulo acabou se mostrando o colégio eleitoral de maior inclinação governista dentro da província durante o Primeiro Reinado. Via de regra, era na capital paulista que homens atrelados a D. Pedro e, após a saída deste, aos opositores à Regência obtinham mais votos, a exemplo de Joaquim Floriano de Toledo (1794-1875). Paulistano de nascimento e amigo do monarca, foi secretário do governo de São Paulo entre 1824 e 1830, além de deputado pela mesma província nas $2^{\mathrm{a}}$, $3^{\mathrm{a}}$ e $4^{\mathrm{a}}$ legislaturas do Império. Era enxergado com certa desconfiança pela dita oposição liberal, que o consideravam inapto para o cargo de deputado por ser "muito dependente do Governo". ${ }^{23}$ Certa feita se indispôs com 0 Farol Paulistano, o qual por meio de uma correspondência insinuou que Joaquim Floriano estava subornando eleitores para chegar à Câmara dos Deputados. ${ }^{24}$ Outra figura próxima ao governo do imperador era o bispo Joaquim Gonçalves

\footnotetext{
${ }^{22}$ Criados em 1823 e estabelecidos a partir do ano seguinte, Conselhos da Presidência foram os principais espaços oficiais de discussão e prática política em escala provincial entre 1824, ano da outorga da Carta constitucional, e a instalação dos Conselhos Gerais de Província, em fins de 1828. Ficaram até 1834 como a única via de atuação política em caráter representativo na esfera dos executivos provinciais. Já os Conselhos Gerais foram o principal canal de participação política em nível provincial até o surgimento das Assembleias Legislativas Provinciais, criadas pelo Ato Adicional (1834) e implantadas a partir de 1835. Cf. OLIVEIRA, Carlos Eduardo França de. Construtores do Império, defensores da província: São Paulo e Minas Gerais na formação do estado nacional e dos poderes locais, 1823-1834. Porto Alegre: Puc-RS, 2017, cap.2.

${ }^{23}$ O Farol Paulistano, n. 165, 19/11/1828.

${ }^{24}$ O Farol Paulistano, n. 169, 03/12/1828.
} 
de Andrade, três vezes vice-presidente da província de São Paulo, entre 1828 e 1831, e figura constante nos Conselhos Geral e da Presidência de São Paulo, sobretudo no segundo. ${ }^{25}$

À medida que o Primeiro Reinado foi tomando forma, a presença de homens avessos ao governo de D. Pedro se fez cada vez mais presente na cidade de São Paulo. A cada ano novos cargos eletivos foram surgindo - conselheiro provincial, deputado, senador, sem contar a magistratura eletiva, com os juízes de paz e o júri -, o que ampliou sensivelmente o acesso à coisa pública. Passados o 7 de abril e a troca sistemática de presidentes de província operada pela Regência, São Paulo alargou o terreno para a ação dos denominados liberais moderados. Há escassas referências, infelizmente, sobre o advogado Manoel Joaquim de Ornelas, uma das figuras de maior destaque na política paulistana durante o Primeiro Reinado, o que fica comprovado na sua participação no Governo Provisório de São Paulo (1823-1824), na eleição para deputado para as $1^{\mathrm{a}}$ e $2^{\mathrm{a}}$ legislaturas do Império e quando ocupou a vice-presidência da província entre fins de 1828 e início de 1829. Dono de votações expressivas, foi membro dos Conselhos Geral e da Presidência, com atuação destacada no segundo órgão. ${ }^{26}$ Outro nome de prestígio entre os liberais paulistanos era o de Antônio Mariano de Azevedo Marques, um dos redatores do jornal o Farol Paulistano, lente de latim e retórica do Curso Jurídico e figura recorrente na política da capital, chegando a participar das $2^{\mathrm{a}}$ e $3^{\mathrm{a}}$ Reuniões dos Conselhos Geral e da Presidência. ${ }^{27}$ Embora ainda não apresentasse a importância que deteria na segunda metade do século XIX, o Curso Jurídico de São Paulo proporcionou, em seus anos iniciais, um fórum de discussão de ideias jurídicas, políticas e artísticas, contribuindo para isso o ingresso de alunos e professores

\footnotetext{
${ }^{25}$ Manoel Joaquim Gonçalves de Andrade era natural da Ilha da Madeira, Portugal. Era filho de Nicolau Gonçalves de Andrade e Maria de Andrade. Formou-se em Cânones pela Universidade de Coimbra, em 1796, ano em que também foi nomeado para um canonicato vago na Sé de São Paulo. Voltando para Portugal, só retornou a São Paulo em 1802, quando ocupou os lugares de arcediago e vigário-geral. Com a morte do bispo D. Mateus de Abreu Pereira, em 1824, foi nesse ano eleito vigário capitular e, em 1826, bispo.

${ }^{26}$ Antes da Independência, Ornelas fora um dos diretores da Caixa de Descontos da cidade e província de São Paulo, cf. C-0366,002, n. 001, 1812-1820. Biblioteca Nacional. Seção de Manuscritos. Ornelas chegou a ser promotor em São Paulo, cf. ofício de 29/09/1829, publicado em O Farol Paulistano, n. 255, 08/10/1829. Faleceu em 1830.

${ }^{27}$ Antônio Mariano de Azevedo Marques (1797-1844) era natural de São Paulo. Filho de Manoel Eufrásio de Azevedo Marques, tornou-se conhecedor de latim já em sua juventude, fazendo com que ministrasse aulas para os integrantes do coral da Catedral da Sé, quando recebeu o apelido de Mestrinho. Em 1822, foi nomeado professor da cadeira pública de Latim e Retórica da cidade de São Paulo. Em 1828, quando da fundação do Curso Jurídico de São Paulo, ocupou a cadeira de Latim e Retórica anexa ao Curso Jurídico, cargo que desempenhou até 1835. Entre as décadas de 1820 e 1830, ocupou os cargos de escrivão da irmandade de Santa Casa de Misericórdia (1823-1825), juiz de paz, vereador, vice-presidente (1837) e secretário da presidência (1839-1842), todos por São Paulo.
} 
de diferentes partes do Império. ${ }^{28}$ Dos bancos da faculdade despontariam naquela época novas caras para a política paulista, como José Antônio Pimenta Bueno $^{29}$, futuro Marquês de São Vicente, e Manoel Dias de Toledo, deputado por São Paulo na $3^{a}$ legislatura e, posteriormente, duas vezes presidente da mesma província. Ambos iniciaram suas carreiras políticas no Conselho Geral de São Paulo.

Trajetórias semelhantes entre si, ao menos no início da carreira política, tiveram os paulistanos Vicente Pires da Mota ${ }^{30}$ e Manoel Joaquim do Amaral Gurgel $^{31}$, ambos padres e colegas de turma do Curso Jurídico de São Paulo, onde mais tarde lecionariam. A longa e diversificada carreira política de Pires da Mota teve início nos Conselhos Geral e da Presidência, assim como Amaral Gurgel, que em 1828 encabeçou a lista de votos na capital paulista para o cargo de conselheiro-geral, quando propôs a fundação de uma cadeira de medicina de São Paulo. ${ }^{32}$ Próximo aos dois era o também padre Ildefonso Xavier Ferreira, figura atuante nos acontecimentos de 1822 e, posteriormente, membro da Sociedade Federal de São Paulo, de inclinação exaltada.

Saindo da capital em direção ao Atlântico, encontra-se o extenso litoral paulista, que nas primeiras décadas do século XIX se dividia, grosso modo, em duas vertentes. A porção sul - compreendida entre Santos e o litoral catarinense - abrigava vilas e freguesias de ocupação remota, as quais aludiam às primeiras investidas portuguesas na então capitania de São Vicente, como Itanhaém, Peruíbe, Cananeia e Iguape. A pouca expressividade econômica da

\footnotetext{
${ }^{28} \mathrm{~A}$ própria categoria "estudante", atualmente associada à ideia de juventude, deve ser relativizada para esse período. Ao lado de um Joaquim Otavio Nebias, nascido em 1811, faziam parte do corpo discente homens como Ildefonso Xavier Ferreira e José Antônio dos Reis, que por sua vez eram contemporâneos de Manoel Joaquim do Amaral Gurgel e Antônio Mariano de Azevedo Marques, também alunos do Curso Jurídico, representantes da "moderação" paulista.

${ }^{29}$ Jose Antônio Pimenta Bueno (1803-1878), o Marquês de São Vicente, era natural de Santos. Filho de José Antônio Pimenta Bueno e Mariana Benedita de Faria e Albuquerque, formou-se em Direto pelo Curso Jurídico de São Paulo. Na política, ocupou diversos cargos, tais como membro da $2^{\mathrm{a}} \mathrm{e} 3^{\mathrm{a}}$ Reuniões do Conselho Geral de São Paulo, entre 1830 e 1834. Cf. SÃo VICENTE, Marquês de. Marquês de São Vicente. Organização e introdução de Eduardo Kugelmas. São Paulo: Editora 34, 2002.

${ }^{30}$ Vicente Pires da Mota (1779-1882) era natural da cidade de São Paulo e, quando do seu ingresso no Curso Jurídico, em 1828, já era presbítero. Tornou-se bacharel em 1832 e, no ano seguinte, foi nomeado lente substituto interino, tal como ocorrera com outros colegas de curso e política, como Manoel Joaquim do Amaral Gurgel e Manoel Dias de Toledo. Em 1833, foi nomeado lente catedrático de direito civil. Como político, iniciou sua carreira como conselheiro da $2^{\mathrm{a}}$ Sessão do Conselho Geral (1830-1833) e da $3^{\mathrm{a}}$ Sessão do Conselho da Presidência (1834), ambos por São Paulo. Cf. AMARAL, Antonio Barreto do. Dicionário de História de São Paulo. São Paulo: Governo do Estado, 1980. p. 321-322.

${ }^{31}$ Amaral Gurgel foi eleito para as três Reuniões do Conselho Geral de São Paulo, entre 1828 e 1834. Em 1833, foi secretário do órgão. No Conselho da Presidência, foi suplente na $2^{\mathrm{a}}$ Sessão e membro efetivo na $3^{\mathrm{a}}$.

${ }^{32}$ O Farol Paulistano, n. 176, 30/12/1828.
} 
região foi parcialmente remediada, no início do século XIX, com a intensificação do cultivo de cereais que, notadamente nas áreas alagadiças, viu proliferar as lavouras de arroz. Se num primeiro momento a rizicultura foi desenvolvida como fonte de subsistência das sociedades da região, gradativamente ela foi tomando contornos de mercado, sendo inclusive produzida por proprietários de terra e escravos que redirecionaram o capital adquirido nos tempos mais lucrativos da mineração. No início do século XIX, o arroz se tornou o principal elemento da balança comercial de Iguape, Xiririca e Iporanga, que mais tarde viriam a formar a área hoje conhecida como vale do Ribeira. ${ }^{33}$ Quando da instalação dos Conselhos Geral e da Presidência, estes receberam seguidas solicitações para a criação de um canal que ligasse a ribeira de Iguape com o mar. ${ }^{34}$ A personalidade política mais afamada da região durante o período foi João Crisóstomo de Oliveira Salgado Bueno, vigário da vila de Iguape, deputado por São Paulo na $1^{\text {a }}$ legislatura e segundo membro mais votado para compor a 1로 Sessão do Conselho Geral. ${ }^{35}$ Já a porção norte do litoral paulista estendia-se de Santos até a divisa com a província do Rio de Janeiro e tinha como destaque os portos de São Sebastião e Ubatuba, que desde o século XVII travavam importante conexão com as vilas e freguesias do vale do Paraíba. Ao longo das rotas que ligavam tais portos com o planalto surgiram vilas como São Luis de Paraitinga - situada no meio do caminho entre Ubatuba e Taubaté - e Cunha, que se interpunha entre Guaratinguetá e Parati. Produzia-se ali açúcar, aguardente e gêneros alimentícios. ${ }^{36}$

Santos abrigava o principal porto da província e constituía a melhor ligação entre o Atlântico e a capital paulista. Era o escoadouro da maior parte da produção oriunda do planalto - cujo produto de maior peso na pauta de exportações ainda era, nas primeiras décadas do século XIX, a cana-de-açúcar - embora ali também circulassem café, carnes, farinha de milho e mandioca, trigo e feijão. ${ }^{37}$ Se durante os séculos XVII e XVIII a importância do porto chegou a diminuir diante do desenvolvimento de outras portas de saída

\footnotetext{
${ }^{33}$ VALENTIN, Agnaldo. Uma civilização do arroz: agricultura, comércio e subsistência no Vale do Ribeira (1800-1880). 2006. Dissertação (Mestrado em História) - Faculdade de Filosofia, Letras e Ciências Humanas, Universidade de São Paulo, 2006.

${ }^{34}$ ATAS do Conselho da Presidência da Província de São Paulo (1824-1834). Documentos interessantes para a história e costumes de São Paulo. São Paulo: Departamento do Arquivo do Estado, 1961, v. 86, sessão de 3/11/1825, p. 79-86.

${ }^{35} \mathrm{Na} 2^{\mathrm{a}}$ Sessão do Conselho Geral de São Paulo (1830-1833) foi eleito como suplente, cf. ALESP, FCGPPO29.002, CX. 22.

${ }^{36}$ MARCÍLIO, Maria Luiza. Caiçara: terra e população. Estudo de demografia histórica e da história social de Ubatuba. São Paulo: Edusp, 2006.
}

${ }^{37}$ PETRONE, Pasquale. Aldeamentos paulistas. São Paulo: Edusp, 1995. 
localizadas na porção norte do litoral paulista - especialmente São Sebastião e Ubatuba-, entre fins dos Setecentos e início dos Oitocentos o "Caminho do Mar" 38 passou por melhorias de infraestrutura que tornaram a ligação entre planalto e litoral mais rápida e segura, consolidando a proeminência de Santos na economia local. ${ }^{39}$

Os principias expoentes políticos da sociedade santista da época foram, sem dúvida, os irmãos Andrada. José Bonifácio, Martim Francisco e Antônio Carlos eram filhos de José Ribeiro de Andrada, rico negociante da vila de Santos que em meados do século XVIII acumulou algumas funções militares e administrativas de prestígio na capitania de São Paulo. ${ }^{40}$ José Bonifácio foi vice-presidente da primeira Junta de Governo de São Paulo (1821-1822), ministro do Reino e dos Estrangeiros (1822-1823) e, depois de seu retorno do exílio, nomeado tutor de D. Pedro II. Martim Francisco foi membro da primeira Junta de Governo de São Paulo (1821-1822), ministro da Fazenda (1822-1823), deputado pela Constituinte pela bancada paulista e, após a volta do exílio, deputado por Minas Gerais para a segunda legislatura. Partícipe da Revolução de 1817, em Pernambuco, Antonio Carlos foi deputado por São Paulo às Cortes (1821) e à Constituinte (1823).

Sobrinho do "patriarca da independência" e filho do coronel Francisco Xavier da Costa Aguiar, negociante com atuação na praça santista desde o período joanino, José Ricardo da Costa Aguiar foi deputado por São Paulo nas Cortes de Lisboa (1821), na Assembleia Constituinte (1823) e na $1^{1 \underline{a}}$ legislatura do Império. ${ }^{41}$ Em virtude da influência dos Andrada, a vila de Santos contaria, ainda mais que São Paulo, com um eleitorado favorável ao governo de D. Pedro. Após a Abdicação, foi um dos principais polos de resistência ao governo regencial.

\footnotetext{
${ }^{38}$ Nome utilizado desde o século XVI para designar o percurso entre a cidade de São Paulo e o litoral santista. Cf. PETRONE, Pasquale. Povoamento e caminhos nos séculos XVI e XVII. In: PETRONE, Pasquale. A Baixada Santista: aspectos geográficos. São Paulo: Edusp, 1965. p. 11-73.

${ }^{39}$ Foram os casos da "Calçada do Lorena" - caminho calçado entre São Paulo e Cubatão, construído na última década do século XVIII - e do aterrado de Cubatão, obra concluída em 1827 e que eliminou o percurso feito por barcas entre Cubatão e o porto santista. Cf. PERALTA, Ines Garbuio. 0 caminho do mar: subsídios para a História de Cubatão. Cubatão: Prefeitura Municipal de Cubatão, 1973.

${ }^{40}$ José Ribeiro de Andrada foi coronel do regimento dos Dragões Auxiliares da capitania de São Paulo, fiscal da Intendência das Minas de Paranapanema (1746), almoxarife da Fazenda Real (1759-64) e escrivão da Junta Real da Fazenda de São Paulo (1768-72). Cf. CAVALCANTE, Berenice. José Bonifácio: razão e sensibilidade, uma história em três tempos. Rio de Janeiro: Editora FGV, 2001.

${ }^{41}$ José Ricardo da Costa Aguiar de Andrada (1787-1846) era natural de Santos e filho de Bárbara Ribeiro de Andrada, irmã de José Bonifácio de Andrada e Silva. Formado em Direito pela Universidade de Coimbra, em 1810, dedicou-se principalmente à magistratura, chegando ao posto de ministro do Supremo Tribunal de Justiça em 1828. Cf. MEDICCI, Administrando conflitos..., p. 219.
} 
Ao leste da capital paulista, estendendo-se por mais de $300 \mathrm{~km}$ num estreito corredor de terras delineado pelas Serras do Mar e da Mantiqueira, espraiava-se o vale do Paraíba paulista, rota de ligação entre São Paulo e Rio de Janeiro. Cenário das primeiras experiências com a cultura cafeeira na província de São Paulo no início do século XIX, o vale do Paraíba paulista dos anos 1820 e 1830 não possuía ainda a pujança econômica das décadas seguintes, tampouco o café apresentava a essa altura a proeminência alcançada futuramente. Sua economia estava baseada, sobretudo, no cultivo de gêneros de subsistência e na criação de animais, embora houvesse indícios de uma mudança no perfil produtivo da região, de modo que as lavouras de café existentes agrupavam-se, majoritariamente, em Areias, Guaratinguetá e Lorena, compondo à época o principal eixo cafeeiro da província. ${ }^{42} \mathrm{~A}$ própria fundação da vila de Bananal, desmembrada de Areias em 1832, esteve relacionada com o enriquecimento pelo café, cuja produção do vale do Paraíba, em 1836, representava dois terços do total da província, a crer nos dados de Daniel Pedro Müller. ${ }^{43}$ Mas o cenário não era igual em todo o Paraíba. Enquanto que vilas situadas na porção setentrional do vale, como Areias e Bananal, tinham uma relação mais estreita com o Rio de Janeiro do que propriamente com São Paulo, valendo-se para isso dos portos de São Sebastião e Ubatuba, localidades como Mogi das Cruzes, Jacareí ou São José eram mais próximas da capital e a ela se atrelavam. ${ }^{44}$ Não é de causar estranheza, portanto, que nesse momento os vale-paraibanos não constituíssem uma força política em nível provincial ou nacional, embora alguns deles tenham alcançado um lugar no Conselho Geral de São Paulo, como Valério de Alvarenga Ferreira (Paraibuna), que também conseguiu se eleger deputado na $3^{a}$ legislatura, Vitoriano Moreira da Costa (Taubaté), Joaquim Silvério de Castro Sousa Medronho (Bananal), Antonio José Pinto (Areias) e Claudio José Machado (Jacareí), este último com participação destacada nas sessões de 1829 e $1830 .{ }^{45}$

Conhecido originalmente como "Sertão do Rio Pardo", o nordeste da província de São Paulo teve sua ocupação iniciada na segunda metade do século XVII, quando das expedições bandeiristas para a região de Batatais

\footnotetext{
${ }^{42}$ LUNA; KLEIN, op. cit., p. 83-84.

${ }^{43}$ MÜLLER, Daniel Pedro. Ensaio d’um quadro estatístico da Província de São Paulo. São Paulo: Imprensa Oficial, 1978. p.124-129.

${ }^{44}$ HOLANDA, Sérgio Buarque de; MAIA, Tom. Vale do Paraiba - velhas fazendas. São Paulo: Companhia Editora Nacional, 1976. p. 11-44.

${ }^{45}$ Todos eles, em diferentes períodos, pediram dispensa do Conselho Geral por motivos de saúde. Cf. Acervo Histórico da Assembleia Legislativa do Estado de São Paulo, Fundo Conselho Geral da Província, FCGP-PO28.012, cx.22; FCGP-PO30.011, cx.33; FCGP-PO31.007, cx.33; FCGP-PO29.001, cx.22; FCGP-PO28.003.
} 
em busca de mão de obra indígena, a fim de comporem as lavouras de cereais desenvolvidas pelos paulistas no planalto. Com a expansão das áreas mineradoras na primeira metade do século XVIII e, sobretudo, com a implementação do Caminho de Goiás - que ligava a cidade de São Paulo às minas goianas -, o povoamento da região se intensificou. Tanto negociantes e tropeiros como sertanistas passaram a circular pelo Caminho de Goiás com frequência cada vez maior, contribuindo para que as áreas adjacentes à estrada fossem ocupadas, geralmente, por roceiros, rancheiros e donos de estabelecimentos como estalagens e pousos. No final do século XVIII e início do XIX, Franca, Batatais e Casa Branca passaram a receber mineiros oriundos de São João-delRei, Jacuí, Baependi e Tamanduá, que para ali se dirigiram, pós-auge do ouro mineiro, em busca de novas terras para a agricultura de gêneros de primeira necessidade e a pecuária leiteira, num momento de redefinição e expansão da economia sul mineira. ${ }^{46}$

São Paulo tinha entre suas figuras de maior destaque na política, entre as décadas de 1820 e 1830, homens que se atrelavam ao chamado "quadrilátero do açúcar”, designação utilizada para dar nome à principal região produtora de açúcar de São Paulo entre fins do século XVIII e primeira metade do século XIX, e que era delimitado pelas vilas de Sorocaba, Piracicaba, Mogi-Guaçu e Piracicaba e Jundiaí, mas também incluía vilas como Itu e São Carlos. ${ }^{47}$ Manoel Rodrigues Jordão, eleito membro para $1^{\mathrm{a}}$ Reunião dos Conselhos da Presidência e Geral de São Paulo, foi um dos principais agricultores, arrematadores de contrato e negociantes paulistas do começo do século XIX, possuindo fazendas de cana-de-açúcar, café, algodão e gêneros de subsistência em Itu, Constituição (Piracicaba), Bananal, Pindamonhangaba, Caçapava, Paraibuna e Itapetininga, além de chácaras na capital paulista. Era casado com Gertrudes Galvão de Oliveira e Lacerda, irmã do marechal de campo Joaquim Mariano Galvão de Moura Lacerda, suplente na $1^{\underline{a}}$ Reunião do Conselho da Presidência, e detentor de engenhos e fazendas de criação de animais em Constituição e Araraquara, bem como de propriedades na região do Brás, na cidade de São Paulo. ${ }^{48}$ Antônia Joaquina Mendes da Silva, prima de Jordão, era esposa do coronel Joaquim José dos Santos, negociante de escravos e proprietário de terras em Jundiaí, cujo filho, Joaquim José dos Santos Filho, exerceu o cargo de conselheiro da Presidência em 1834. Ana Vicência

\footnotetext{
${ }^{46}$ BACELLAR, Carlos de Almeida Prado; BRIOSCHI, Lucilia Reis. Na estrada do Anhanguera: uma visão regional da história paulista. São Paulo: Humanitas, 1999.

${ }^{47}$ PETRONE, A lavoura canavieira em São Paulo..., op. cit.

${ }^{48}$ ARAÚJO, op. cit., p. 153-156.
} 
Rodrigues Jordão, irmã do brigadeiro Jordão, casou-se com Antônio da Silva Prado, com quem teve um filho, homônimo do pai e futuro Barão de Iguape. Maria Marcolina Prado, prima do Barão de Iguape, contraiu matrimônio com um dos filhos de Lucas Antônio Monteiro de Barros, o magistrado Rodrigo Antônio Monteiro de Barros, dono de uma sociedade de comércio de bestas em Moji das Cruzes e que chegou a ser deputado pela bancada paulista na $1^{\text {a }}$ legislatura do Império. ${ }^{49}$

Outros importantes vínculos familiares e de negócios foram selados pela união dos ituanos Barros Leite com os Souza Queiróz. O brigadeiro Luis Antônio de Sousa Queirós ${ }^{50}$, um dos homens mais ricos de São Paulo no início do século XIX, possuidor de diversos engenhos, de um grande plantel de escravos e de extensas faixas de terra na região de São Carlos, casou-se, em 1797, com Genebra de Barros Leite, filha de Antônio de Barros Penteado e irmã de Antônio Paes de Barros ${ }^{51}$, deputado por São Paulo na $2^{a}$ legislatura do Império, membro do Conselho Geral paulista e esposo de uma irmã de Rafael Tobias de Aguiar. Após a morte do marido, a viúva Genebra de Barros Leite casou-se, em 1822, como já visto, com José da Costa Carvalho, na época ouvidor da capital paulista. ${ }^{52}$

A origem modesta não impediu que o padre paulistano Diogo Antônio Feijó fosse proprietário de engenhos de açúcar naquela vila e, na capital paulista, um dos principais cultivadores de chá. Foi duas vezes deputado por

\footnotetext{
${ }^{49}$ PETRONE, Maria Thereza Schorer. O Barão de Iguape: um empresário na época da independência. São Paulo: Companhia Editora Nacional, 1976; MARQUES, Manuel Eufrásio de Azevedo. Apontamentos históricos, geográficos, biográficos, estatísticos e noticiosos da Província de São Paulo seguidos da Cronologia dos acontecimentos mais notáveis desde a fundação da Capitania de São Vicente até o ano de 1876. São Paulo: Comissão do IV Centenário da cidade de São Paulo, 1954; TAUNAY, Afonso de Escragnolle. História da cidade de São Paulo sob o Império: 1822-1831. São Paulo: Divisão do Arquivo Histórico, 1956.

${ }^{50}$ Luís António de Sousa Queirós (1746-1819) era natural de Amarante. Militar, atingiu a patente de brigadeiro em 1818. Dono de propriedades agrícolas e negociante - inclusive com representação na praça do Rio de Janeiro -, possuía uma das maiores fortunas da província de São Paulo no século XIX. Cf. LEONZO, Nanci. Um empresário nas milícias paulistas: o Brigadeiro Luís Antônio de Sousa. Anais do Museu Paulista, São Paulo, v. 30, p. 241-254, 1981.

${ }^{51}$ Antonio Paes de Barros (1791-1876), futuro Barão de Piracicaba, era natural de Itu. Em 1819, casou-se com Gertrudes Eufrosina Aires de Aguiar, irmã do Brigadeiro Rafael Tobias de Aguiar, no mesmo ano em que seu irmão Bento Paes de Barros - futuro barão de Itu -, casou-se com Leonarda, irmã de Gertrudes. Antes de ser deputado pelo Império, havia sido eleito segundo suplente das Cortes de Lisboa, em 1821. Foi eleito suplente nas $1^{\mathrm{a}}$ e $2^{\mathrm{a}}$ Legislaturas do Conselho do Governo da Presidência de São Paulo e membro efetivo das $1^{\mathrm{a}}, 2^{\mathrm{a}}$ e $3^{\mathrm{a}}$ Legislaturas do Conselho Geral da Província.

${ }^{52}$ BITTENCOURT, Vera Lúcia Nagib; HÖRNER, Erik; MEDICCI, Ana Paulo. "Do ponto à trama, rede de negócios e espaços políticos em São Paulo, 1765-1842". In OLIVEIRA, Cecília Helena L. de Salles; BITTENCOURT, Vera Lúcia N.; COSTA, Wilma Peres (Orgs.). Soberania e conflito: configurações do estado nacional no Brasil do século XIX. São Paulo: Hucitec, 2010. p. 417-444. p. 417-444.
} 
São Paulo ( $2^{\underline{a}}$ e $3^{\underline{a}}$ legislaturas), membro do Conselho da Presidência ( $1^{\underline{a}}$ e $2^{\text {a }}$ Reuniões) e do Conselho Geral ( $1^{\underline{a}}$ e $2^{\underline{a}}$ Reuniões), apenas para citar os cargos desempenhados em sua província natal..$^{53}$ Feijó tinha aliados em Minas, sobretudo no sul mineiro, província que lhe prestou apoio quando ministro na Regência (1831-1832) e que mais contribuiu para sua eleição ao posto de regente único, em $1835 .{ }^{54} \mathrm{Na}$ Corte, a pena e as articulações de Evaristo da Veiga, redator de A Aurora Fluminense, eram seu principal ponto de apoio, trunfos que foram decisivos na chegada do padre paulistano ao Senado, pelo Rio de Janeiro, em 1833.55

O ituano Francisco de Paula Sousa e Melo, deputado pelas $2^{\mathrm{a}}$ e $3^{\mathrm{a}}$ legislaturas do Império e conselheiro-geral nas $2^{\mathrm{a}}$ e $3^{\mathrm{a}}$ Reuniões, em ambos os casos por São Paulo, casou-se com Maria de Barros Leite, irmã de Antônio Paes de Barros. Já o coronel de milícias Francisco Inácio de Sousa Queirós, filho da paulista Isabel Inácia da Conceição e do português Francisco Antônio de Souza e membro dos Conselhos da Presidência ( $1^{\mathrm{a}}$ Sessão) e Geral ( $2^{\mathrm{a}}$ e $3^{\mathrm{a}}$ Reuniões) de São Paulo, casou-se com sua prima Francisca Miquelina de Sousa Queirós, filha do brigadeiro Luis Antônio. Paralelamente à carreira militar, Francisco Inácio foi negociante de alimentos e escravos e dono de engenhos na região de São Carlos. A região contava ainda com outras figuras de projeção, como José Corrêa Pacheco e Silva, deputado por São Paulo nas $1^{\mathrm{a}}$, $2^{\mathrm{a}}$ e $3^{\mathrm{a}}$ legislaturas e membro do Conselho Geral, e Francisco Álvares Machado de Vasconcelos, deputado por São Paulo na $3^{a}$ legislatura. ${ }^{56}$

Embora integrante do "quadrilátero do açúcar", a vila de Sorocaba notabilizava-se por outra atividade econômica - o negócio do gado, um importante

\footnotetext{
${ }^{53}$ FEIJÓ, Diogo Antônio. Diogo Antônio Feijó. Organização e prefácio de Jorge Caldeira. São Paulo: Editora 34, 1999. (Coleção Formadores do Brasil); EGAS, Eugênio. Diogo Antônio Feijó. São Paulo: Tipografia Levi, 1912; RICCI, Magda. Assombrações de um padre regente: Diogo Antônio Feijó (1784-1843). Campinas: Unicamp, 2001. ${ }^{54}$ ANDRADE, Marcos Ferreira de. "Família e política nas Regências: possibilidades interpretativas das cartas pessoais de Evaristo da Veiga (1836-1837)". In RIBEIRO, Gladys Sabina; FERREIRA, Tânia Maria Tavares Bessone da Cruz Ferreira (Orgs.). Linguagens e práticas da cidadania no século XIX. São Paulo: Alameda Editorial, 2010. p. 266.

${ }^{55}$ SOUSA, Otávio Tarquínio de. História dos fundadores do Império do Brasil. Rio de Janeiro: José Olympio Editora, 1957.

${ }^{56}$ José Corrêa Pacheco e Silva (1778-1836) era natural de Itu e formado em Direito pela Universidade de Coimbra. Exerceu o cargo de juiz de fora e ouvidor-geral da cidade de São Paulo de setembro de 1822 a março de 1825. Entre 10 de setembro de 1822 e 9 de janeiro de 1823, foi membro do Governo provisório de São Paulo criado pela carta régia de 25 de junho de 1822, acumulando a função de secretário. Em 1827, ocupou o cargo de ouvidor da Câmara de Castro. Deputado por São Paulo nas $1^{\mathrm{a}}, 2^{\mathrm{a}}$ e $3^{\mathrm{a}}$ legislaturas, ainda foi membro do Conselho Geral da Província de São Paulo em 1830. Morava em Itu, cf. FCGP-PO30.001, cx.23. Francisco Álvares Machado de Vasconcellos (1776-1846) era natural de Porto Feliz, São Paulo, e filho de Teobaldo Machado e Vasconcelos e Maria Álvares da Silva Bueno. Cirurgião médico, um dos pioneiros da oftalmologia no Brasil, também percorreu carreira política. Foi deputado por São Paulo na $3^{a}$ Legislatura.
} 
dinamizador econômico e político da região centro-Sul, posto que o comércio de reses e muares articulava os centros produtores (Rio Grande do Sul e os "Campos Gerais" de Curitiba) e vendedores (Sorocaba e a cidade de São Paulo) com os compradores (região planaltina paulista, Minas Gerais e, sobretudo, o Rio de Janeiro). ${ }^{57}$ O principal nome da política foi o sorocabano Rafael Tobias de Aguiar, deputado nas $2^{a}$ e $3^{a}$ legislaturas do Império, membro do Conselho da Presidência e do Conselho Geral nas $1^{\mathrm{a}}$ e $2^{\mathrm{a}}$ Reuniões e presidente da província de São Paulo entre 1831 e 1834. Tobias de Aguiar era um próspero comerciante de reses e muares na região, além de deter negócios no ramo da cobrança de impostos de animais e tavernas, chegando a receber o título de tesoureiro administrador de Sorocaba entre 1826 e $1829 .{ }^{58}$ Ramo similar ao do curitibano Lourenço Pinto de Sá Ribas, duas vezes deputado ( $2^{\mathrm{a}}$ e $3^{\mathrm{a}}$ legislaturas), membro dos Conselhos da Presidência e Geral e integrante de uma das famílias mais poderosas da vila de Curitiba. ${ }^{59}$ Procedente da região era Anastácio de Freitas Trancoso, coronel de ordenanças de Paranaguá e Curitiba e membro na $2^{a}$ Sessão do Conselho Geral de São Paulo. Trancoso possuía plantações de chá no sítio da Freguesia do Ó, na capital paulista, além de propriedades nas imediações das estradas para Campinas e Santos.

Com as informações acima apresentadas não se tem a presunção de expor uma relação rígida entre segmentos socioeconômicos e orientação/ desempenho político, tampouco fixar uma análise prosopográfica típica. ${ }^{60}$ A atuação dos setores proprietários do centro-sul, porque tensionada pelo mundo dos negócios e da política, acabava implicando em pontos de contato entre homens de formação, posição social e projeção pública diferenciados. Veja-se, por exemplo, a figura de Estevão Ribeiro de Rezende ${ }^{61}$, futuro Marquês

\footnotetext{
${ }^{57}$ BACELLAR, Carlos de Almeida Prado. Família e sociedade em uma economia de abastecimento interno (Sorocaba, séculos XVIII X XIX). 1994. Tese (Doutorado em História) - Faculdade de Filosofia, Letras e Ciências Humanas, Universidade de São Paulo, São Paulo, 1994; BACELLAR, Carlos de Almeida Prado. Viver e sobreviver em uma vila colonial: Sorocaba XVIII e XIX. São Paulo: Annablume/FAPESP, 2001.

${ }^{58}$ PETRONE, O Barão de Iguape..., op. cit., p. 128; ALEIXO IRMÃO, José. Rafael Tobias de Aguiar: o homem, o político. Sorocaba: Fundação Ubaldino do Amaral, 1992; ALMEIDA, Aluísio de. Rafael Tobias de Aguiar, 1794-1857. Revista do Arquivo Público de São Paulo, v. 86, ano 8, out.-nov. 1942.

${ }^{59}$ NEGRÃO, Francisco. Genealogia paranaense. Curitiba: Imprensa Oficial Estado do Paraná, 1927. Na vila de Curitiba, Lourenço Pinto de Sá Ribas desempenhou diversos cargos públicos: vereador (1810-1815, 1826), almotacé (1811), juiz de medições (1818) e presidente da Câmara Municipal (1826-1830, 1831). Cf. BORGES, Luiz Adriano Gonçalves. Particularidades familiares. A trajetória de Manuel Mendes Leitão no Paraná, século XIX. 2009. Dissertação (Mestrado em História) - Setor de Ciências Humanas, Letras e Artes, Universidade Federal do Paraná, 2009.

${ }^{60}$ STONE, Lawrence. "Prosopografia”. Rev. Sociol. Polit. [online]. 2011, vol.19, n.39, p.115-137.

${ }^{61}$ Estevão Ribeiro de Rezende (1777-1856), o Marquês de Valença, nasceu no arraial dos Prados, Comarca do Rio das Mortes, em Minas Gerais. Formado em Leis em Coimbra (1804), ocupou em Portugal o cargo
} 
de Valença, mineiro da Comarca do Rio das Mortes que durante a regência e o reinado de D. João havia sido juiz de fora de São Paulo, fiscal dos diamantes no Serro Frio e ajudante do intendente-geral da polícia no Rio de Janeiro. 0 deslanche político de Estevão Ribeiro só aconteceu de fato quando ele tornou-se homem de confiança de D. Pedro, ao desempenhar papel fundamental durante a viagem feita pelo príncipe regente a Minas Gerais entre março e abril de 1822, cujo objetivo fora reverter o quadro de não adesão à Regência pela Junta governativa mineira.

Em contrapartida, como integrante do Conselho dos ProcuradoresGerais da província de Minas Gerais, em 1822, sua atuação esteve atrelada à tentativa de aplicação de medidas econômicas liberais cujo teor obtinha respaldo nas camadas de proprietários e comerciantes ainda afastadas da máquina pública, mas que após a Abdicação tornar-se-iam gestoras de grande parte dos postos administrativos do período regencial. Dentre suas intervenções mais significativas, defendeu uma reforma tributária que revisse os princípios da arrematação de contratos - um dos pilares da estrutura tributária colonial - com o intuito de promover a desobstrução na circulação de mercadorias e permitir uma maior acumulação de capital, fortalecendo assim tanto a economia de exportação quanto aquela associada ao mercado interno. Se tais medidas não foram estabelecidas de pronto, ao menos ajudaram a compor o debate que estabeleceria as políticas de liberalização de mercado do Primeiro Reinado. ${ }^{62}$

Sócio e amigo de Nicolau de Campos Vergueiro, parente e conselheiro de José da Costa Carvalho - figuras centrais entre os liberais paulistas do final da década de 1820 e primeira metade da década de 1830 -, Estevão Ribeiro beneficiou-se de sua relação com tais homens, assim como estes se valeram do prestígio do político mineiro. Quando participante da intitulada "bernarda" de Francisco Inácio, ocorrida em São Paulo em maio de 1822, Costa Carvalho utilizou-se da sua influência com Estevão Ribeiro, na época muito próximo a D. Pedro, para que sua punição em relação ao levante fosse atenuada, o que de fato

de juiz de fora, em Palmela. De volta ao Brasil, foi juiz de fora de São Paulo (1811), fiscal dos diamantes no Serro Frio (1816) e ajudante do intendente-geral da polícia no Rio de Janeiro (1817). Na política, foi integrante do Conselho dos Procuradores-Gerais da província de Minas Gerais (1822), ministro de estado interino (1822) e senador do Império (1826-1856). Cf. OLIVEIRA, Carlos Eduardo França de. "Estevão Ribeiro de Rezende, o Marquês de Valença: política, magistratura e construção do Estado Nacional”. In Embornal. Revista eletrônica da ANPUH-CE, v. 1, p. 1-18, 2010.

${ }^{62}$ BITTENCOURT, Vera Lúcia Nagib. "O lugar da política: a atuação de Estevão Ribeiro de Rezende, Marquês de Valença”. In OLIVEIRA, Cecilia Helena de Salles; PRADO, Maria Ligia Coelho; JANOTTI, Maria de Lourdes de Mônaco (Orgs.). A história na política, a política na história. São Paulo: Alameda, 2006, p. 94. 
ocorreu. ${ }^{63} \mathrm{O}$ político mineiro, por sua vez, foi um dos poucos ministros poupados das contundentes críticas feita pelo periódico paulista $O$ Farol Paulistano no ano de 1827, que tinha Costa Carvalho como diretor e um dos seus redatores.

Outro nome que demanda um olhar mais cuidadoso sobre o relacionamento entre diferentes grupos políticos por meio dos negócios e laços de família é o de Rafael Tobias de Aguiar. A íntima relação com a região de Sorocaba e Caminho do Sul não lhe obstou travar contato com o já citado João Rodrigues Pereira de Almeida, futuro Barão de Ubá, figura que se enriqueceu e projetou publicamente durante o governo joanino, chegando a dirigir o Banco do Brasil. Tobias de Aguiar herdou associação estabelecida por seu pai - Antônio Francisco de Aguiar - com Pereira de Almeida, responsável por adquirir e vender na praça do Rio de Janeiro animais oriundos das feiras de Sorocaba.

Quando o foco do estudo passa do Rio de Janeiro para as províncias, percebe-se que até mesmo a ideia dos "clãs" familiares que se consolidaram no período joanino e Primeiro Reinado ganha outros contornos. Muitas dessas redes familiares eram compostas por homens de posição, função e atuação política distintas que não podem ser resumidas unicamente a fidelidades de ordem de origem, de condição socioeconômica ou de inclinação político-ideológica. Em muitos casos, há uma assimetria entre nível de riqueza e projeto político, constatação que remonta a um desafio permanente dentro dos estudos de história política, que é o da articulação entre o lugar socioeconômico e a manifestação política de determinado grupo. ${ }^{64}$

Grupos familiares como os Monteiro de Barros sinalizam um quadro nuançado e mutante em que a dicotomia centro/província, geralmente identificada para o Primeiro Reinado como um desdobramento do embate entre governo e oposição, ou até mesmo entre centralização e descentralização, deve ser matizada. Se é verdadeiro afirmar que os Monteiro de Barros, por exemplo, nunca estiveram entre as lideranças liberais - posicionamento que ganhou nitidez com o "Regresso" e, mais especificamente, em meio à Revolução Liberal de 1842 -, também é necessário considerar que a atuação desses homens foi pautada pelas diferentes circunstâncias em que exerceram o poder, ora na província, ora no Rio de Janeiro. É evidente que uma vez alocados no Senado, nomes como Lucas Antonio Monteiro de Barros - um dos poucos membros vitalícios cuja figura política foi preservada pelos liberais moderados durante

\footnotetext{
${ }^{63}$ TAUNAY, História da cidade de São Paulo..., op. cit.

${ }^{64}$ HUNT, Lynn. Política, cultura e classe na Revolução Francesa. Tradução de: Laura Teixeira Motta. São Paulo: Companhia das Letras, 2007. p. 32-33.
} 
o Primeiro Reinado e início da Regência - estivessem mais afinados com o governo pedrino e, posteriormente, com a resistência caramuru. Na Câmara dos Deputados, onde o elemento liberal preponderou de 1826 a 1837, a articulação com setores moderados se fazia necessária a depender da situação, tanto que um Rodrigo Antonio Monteiro de Barros não chegou a ser atacado pelos moderados por ter se aliado, nas eleições para a $3^{\underline{a}}$ legislatura, ao grupo dos Andrada. De qualquer forma, seja na Câmara ou no Senado, os laços econômicos, políticos e familiares que mantinham com a província implicavam numa série de mediações e negociações que iam desde a aprovação de resoluções dos Conselhos Gerais e dos orçamentos provinciais, do fomento de leis que ampliavam a autonomia das províncias até a emissão de vereditos sobre crimes políticos ocorridos por todo território nacional. Na esfera provincial, por sua vez, as relações se davam de forma mais pulverizada, atreladas que eram às disputas e demandas urgentes das localidades. ricos proprietário tiveram que lidar com a aprovação de posturas e contas municipais, confrontar projetos voltados para as necessidades das freguesias e vilas, além de mediar a atuação de juízes de paz, ouvidores e outros funcionários públicos.

\section{Considerações finais}

Nos anos 1820, longe de constituir uma província estagnada ou em declínio, São Paulo apesentava uma considerável variedade de atividades econômicas que abriam possibilidades diferenciadas de inserção na produção agrícola, no mercado e no universo da política. A diversidade de situações seja no alicerce político de D. Pedro, seja entre os que lhe faziam oposição e depois sustentariam a Regência - implica num questionamento, ao menos para São Paulo, da ideia das províncias nas primeiras décadas do século XIX como "forças centrífugas", arredias, descrentes do comando do Rio de Janeiro. Em contrapartida, a situação se torna mais complexa quando se recupera a bibliografia tradicional sobre a participação de São Paulo na Independência, que em grande medida vê a existência de um "adesismo" mais ou menos consensual em torno do projeto de poder encabeçado por D. Pedro. Tese que vem sendo contestada por estudos mais recentes, os quais vêm apontando para uma solução negociada entre setores provinciais e o círculo de D. Pedro, tendo como pano de fundo uma maior inserção nas redes de poder e negócios proporcionadas por um novo governo sediado no Rio de Janeiro. ${ }^{65}$

${ }^{65}$ DELATORRE, Aparecida Vanessa. São Paulo à época da Independência: contribuição para o estudo do chamado movimento "bernardista", 1821/1823. 2003. Dissertação (Mestrado em História Social) - Faculdade 
Os principais nomes dentre os paulistas que apoiavam d. Pedro ao longo do Primeiro Reinado estavam de fato na Corte, vivenciavam a política da capital e tinham nas pastas ministeriais, no Conselho de Estado, no Senado e em alguns postos altos da magistratura e do Banco do Brasil sua reserva de poder. Entretanto, esses personagens mais próximos ao círculo pedrino assistiram à progressiva ascensão de interlocutores variados dentro da política, resultado da luta por mercados, terras, capital e poder. Donos de engenhos de cana-de-açúcar e de lavras, produtores e comerciantes de gêneros de primeira necessidade, criadores e negociantes de tropas de burro, esses homens, especialmente oriundos do Rio de Janeiro, Minas Gerais e São Paulo, tiveram papel fundamental nos debates ocorridos nas Cortes de Lisboa, na viabilização do "Fico", na composição das Juntas de Governo e no endosso (ainda que momentâneo) à Carta de 1824, mas não chegaram a ser recrutados por d. Pedro para o Ministério. Acabaram organizando-se, alternativamente, nas esferas de poder as quais dependiam de processos eleitorais, tais como as Câmaras Municipais, os Conselhos Provinciais e, em especial, a Câmara dos Deputados, divisando nas sucessivas convocações do Parlamento, a partir de 1826, um modo de abrir espaço político na Corte, ampliando sua rede de negócios e projeção política. Tais espaços, no entanto, também foram granjeados fora das esferas oficiais de poder e dos negócios, como por exemplo, pela imprensa periódica. Não à toa que ao longo das primeiras legislaturas viriam a formar um dos principais grupos de combate ao governo de d. Pedro, os chamados liberais moderados.

Salvo alguns poucos nomes, os deputados paulistas mais atuantes e com maior projeção no Rio de Janeiro nas duas primeiras legislaturas do Império (1826-1829, 1830-1833) ${ }^{66}$ vieram a compor uma fração importante

de Filosofia, Letras e Ciências Humanas, Universidade de São Paulo, São Paulo, 2003; DOLHNIKOFF, Miriam. São Paulo na Independência. In: JANCSÓ, István (Org.). Independência: história e historiografia. São Paulo: Hucitec/FAPESP, 2005, p. 557-575; NEVES, Lucia Maria Bastos Pereira das. São Paulo e a Independência. In: SILVA, Maria Beatriz Nizza da (Org.). História de São Paulo colonial. São Paulo: Ed. UNESP, 2009. p. 275-318; OLIVEIRA, Cecilia Helena de Salles. "São Paulo e a Independência". In: CAMARGO, Ana Maria de Almeida (Org.). São Paulo, uma longa história. São Paulo: Centro de Integração Escola/Empresa, 2004. p. 39-58.

${ }^{66}$ Deputados eleitos pela província de São Paulo para a primeira legislatura (1826-29): Nicolau Pereira de Campos Vergueiro, José Ricardo da Costa Aguiar de Andrada, Manoel Joaquim de Ornelas, José Corrêa Pacheco e Silva, José Arouche de Toledo Rendon (não tomou posse. Foi substituído pelo brigadeiro Inácio José Vicente da Fonseca), Francisco de Paula Sousa e Melo, Francisco das Chagas Santos, Diogo Antonio Feijó (tomou assento como suplente do Visconde de São Leopoldo, nomeado Senador em abril de 1826), João Crisóstomo de Oliveira Salgado Bueno (Suplente de José da Costa Carvalho, que optou pela deputação da Bahia). Deputados paulistas eleitos para a segunda legislatura (1830-33): Francisco de Paula Sousa e Melo, Diogo Antonio Feijó, Manoel Joaquim de Ornelas (após seu falecimento, foi substituído em 1832 e 1833 pelo Padre Francisco de Paula Simões), Rafael Tobias de Aguiar (Em 1832 e 1833 substituiu-o o Padre Valério de Alvarenga Ferreira), José Corrêa Pacheco e Silva, Antonio Paes de Barros, Lourenço Pinto de Sá Ribas, Rodrigo Antonio Monteiro de Barros, Joaquim Floriano de Toledo (Tomou assento como Suplente 
dessa heterogênea oposição ao governo pedrino, que, com a Abdicação, passou a apoiar e compor a Regência. Entre os representantes eleitos por São Paulo é possível observar a predominância de políticos associados ao oeste paulista, região marcada pelas lavouras exportadoras de cana-de-açúcar e, no caso de Sorocaba e imediações, pela comercialização de gado proveniente do Rio Grande do Sul. Conforme visto, Vergueiro, Pacheco e Silva, Paula Sousa, Feijó, Costa Carvalho, Paes de Barros e Monteiro de Barros residiam ou possuíam negócios em Itu, Constituição e Atibaia, assim como Rafael Tobias de Aguiar e Lourenço Pinto de Sá Ribas estavam no ramo da venda de animais que ligava Sorocaba, Curitiba e Rio Grande. Dentre esses homens apenas Paes de Barros e Monteiro de Barros não participariam, pelo que sugerem as fontes, da oposição ao governo de D. Pedro e da base política das Regências Provisória e Permanente. Políticos com raízes em outras regiões da província - como Salgado Bueno e Costa Aguiar (litoral sul), Valério da Alvarenga Ferreira (vale do Paraíba), Ornelas, Toledo Rendon e Floriano de Toledo (cidade de São Paulo) - constituíram minoria na bancada paulista. Feita exceção ao litoral sul da província - incluindo-se aí Santos, Iguape e Paranaguá -, que ofereceu resistência à ascensão de políticos do oeste paulista e, por causa da influência dos Andrada, um suporte maior ao governo de D. Pedro, opondo-se posteriormente à Regência, essas localidades apresentaram um perfil político mais dividido com relação à escolha dos representantes para a Câmara dos Deputados.

Poucos aliados de D. Pedro e do seu círculo de ministros elegeram-se deputados por São Paulo nas duas primeiras legislaturas. O principal deles foi José Feliciano Fernandes Pinheiro, elevado a Marquês de Santo Amaro em 1826, mas que acabou optando pelo Senado. Em menor grau, pode-se mencionar Joaquim Floriano de Toledo, assim como José Ricardo da Costa Aguiar, que fora colocado pelo monarca, em 1828, no recém-criado Supremo Tribunal de Justiça. Filho de Lucas Antônio Monteiro de Barros, escolhido presidente de São Paulo justamente em 1824, Rodrigo Antônio Monteiro de Barros possivelmente cultivou alguma relação com figuras mais próximos ao monarca, tanto que nas eleições para a terceira legislatura sua candidatura esteve atrelada ao núcleo dos Andrada, mas não há notícia de que tenha sido um adversário de relevo daqueles que fariam oposição ao governo pedrino. Mesmo assim, é muito pouco, por isso não é banal o fato de que nas eleições para as duas primeiras legislaturas não se registrou o sucesso de nenhum

de José da Costa Carvalho, que optou pela deputação da Bahia). Cf. TAUNAY, Afonso de Escragnolle. A Câmara dos deputados sob o Império. São Paulo: Imprensa Oficial do Estado de São Paulo, 1950. p. 115-122. 
candidato de renome que já era ou se tornaria coligado ao monarca - um presidente de província, por exemplo, como foi de praxe em outras localidades do Império.

Apesar de ser irrefutável o fato de que houve uma progressiva escalada da oposição ao governo durante o Primeiro Reinado, não se deve esquecer que essa manteve uma unidade aparente, porém necessária diante da existência de um adversário em comum - o Executivo e parte do Senado. As divergências existentes da oposição - sobretudo entre liberais moderados, exaltados e entre o próprio núcleo moderado - aflorariam com maior nitidez após o 7 de abril, quando aqueles que a compunham passaram a lutar entre si pelo poder.

\section{Referências}

ABUD, Kátia Maria. Autoridade e riqueza. Contribuição para o estudo da sociedade paulistana na segunda metade do século XVIII. 1978. Dissertação (Mestrado em História Social) - Faculdade de Filosofia, Letras e Ciências Humanas, Universidade de São Paulo, São Paulo, 1978.

ALEIXO IRMÃO, José. Rafael Tobias de Aguiar: o homem, o político. Sorocaba: Fundação Ubaldino do Amaral, 1992.

ALMEIDA, Aluísio de. Rafael Tobias de Aguiar, 1794-1857. Revista do Arquivo Público de São Paulo, v. 86, ano 8, out.-nov. 1942.

AMARAL, Antonio Barreto do. Dicionário de História de São Paulo. São Paulo: Governo do Estado, 1980. p. 321-322.

ANDRADE, Marcos Ferreira de. "Família e política nas Regências: possibilidades interpretativas das cartas pessoais de Evaristo da Veiga (1836-1837)”. In RIBEIRO, Gladys Sabina; FERREIRA, Tânia Maria Tavares Bessone da Cruz Ferreira (Orgs.). Linguagens e práticas da cidadania no século XIX. São Paulo: Alameda Editorial, 2010. p. 247-272.

ARAÚJO, Maria Lucília Viveiros. Os caminhos da riqueza dos paulistanos na primeira metade do oitocentos. São Paulo: Hucitec/Fapesp, 2006.

ATAS do Conselho da Presidência da Província de São Paulo (1824-1834).

Documentos interessantes para a história e costumes de São Paulo. São Paulo:

Departamento do Arquivo do Estado, 1961, v. 86. 
BACELLAR, Carlos de Almeida Prado. Familia e sociedade em uma economia de abastecimento interno (Sorocaba, séculos XVIII e XIX). 1994. Tese (Doutorado em História) - Faculdade de Filosofia, Letras e Ciências Humanas, Universidade de São Paulo, São Paulo, 1994.

- Viver e sobreviver em uma vila colonial: Sorocaba XVIII e XIX. São Paulo: Annablume/FAPESP, 2001.

; BRIOSCHI, Lucilia Reis. Na estrada do Anhanguera: uma visão regional da história paulista. São Paulo: Humanitas, 1999.

BITTENCOURT, Vera Lúcia Nagib. De alteza real a imperador: o governo do Príncipe D. Pedro, de abril de 1821 a outubro de 1822. 2007. Tese (Doutorado em História) Faculdade de Filosofia, Letras e Ciências Humanas, Universidade de São Paulo, São Paulo, 2007.

. "O lugar da política: a atuação de Estevão Ribeiro de Rezende, Marquês de Valença”. In OLIVEIRA, Cecilia Helena de Salles; PRADO, Maria Ligia Coelho; JANOTTI, Maria de Lourdes de Mônaco (Orgs.). A história na política, a política na história. São Paulo: Alameda, 2006, p.81-98.

. BITTENCOURT, Vera Lúcia Nagib; HÖRNER, Erik; MEDICCI, Ana Paulo. "Do ponto à trama, rede de negócios e espaços políticos em São Paulo, 1765-1842”. In OLIVEIRA, Cecília Helena L. de Salles; BITTENCOURT, Vera Lúcia N.; COSTA, Wilma Peres (Orgs.). Soberania e conflito: configurações do estado nacional no Brasil do século XIX. São Paulo: Hucitec, 2010. p. 417-444.

BORGES, Luiz Adriano Gonçalves. Particularidades familiares. A trajetória de Manuel Mendes Leitão no Paraná, século XIX. 2009. Dissertação (Mestrado em História) Setor de Ciências Humanas, Letras e Artes, Universidade Federal do Paraná, 2009.

BORREGO, Maria Aparecida de Menezes. A teia mercantil: negócios e poderes em São Paulo colonial (1711-1765). São Paulo: Alameda/Fapesp, 2010.

BRUNO, Ernani da Silva. História e tradições da cidade de São Paulo. Rio de Janeiro: José Olympio, 1953.

OLIVEIRA, Cecilia Helena L. de Salles. A astúcia liberal. Relações de Mercado e Projetos Políticos no Rio de Janeiro (1820-1824). São Paulo: Ícone e Edusf, 1999, p.80.

CANABRAVA, Alice. "Uma economia de decadência: os níveis de riqueza na Capitania de São Paulo, 1765/1767". In Revista Brasileira de Economia. Rio de Janeiro, v. 26, n. 4, p. 95-123, out.-dez. 1972. 
CAVALCANTE, Berenice. José Bonifácio: razão e sensibilidade, uma história em três tempos. Rio de Janeiro: Editora FGV, 2001.

DELATORRE, Aparecida Vanessa. São Paulo à época da Independência: contribuição para o estudo do chamado movimento "bernardista”, 1821/1823. 2003. Dissertação (Mestrado em História Social) - Faculdade de Filosofia, Letras e Ciências Humanas, Universidade de São Paulo, São Paulo, 2003.

DOLHNIKOFF, Miriam. São Paulo na Independência. In: JANCSÓ, István (Org.). Independência: história e historiografia. São Paulo: Hucitec/FAPESP, 2005. p. 557-575.

EGAS, Eugênio. Diogo Antônio Feijó. São Paulo: Tipografia Levi, 1912.

ELLIS JR., Alfredo. A economia paulista no século XVIII: ciclo do muar, ciclo do açúcar. São Paulo: Academia Paulista de Letras, 1979.

FEIJÓ, Diogo Antônio. Diogo Antônio Feijó. Organização e prefácio de Jorge Caldeira. São Paulo: Editora 34, 1999.

FRAGOSO, João Luiz Ribeiro. Homens de grossa aventura: acumulação e hierarquia na praça mercantil do Rio de Janeiro (1790-1830). Rio de Janeiro: Arquivo Nacional, 1992.

GODOY, Marcelo Magalhães. Intrépidos viajantes e a construção do espaço: uma proposta de regionalização para as Minas Gerais do século XIX. Belo Horizonte: UFMG/Cedeplar, 1996.

HOLANDA, Sérgio Buarque de; MAIA, Tom. Vale do Paraíba - velhas fazendas. São Paulo: Companhia Editora Nacional, 1976. p. 11-44.

HUNT, Lynn. Política, cultura e classe na Revolução Francesa. Tradução de: Laura Teixeira Motta. São Paulo: Companhia das Letras, 2007.

JANCSÓ, István. “A construção dos Estados Nacionais na América Latina. Apontamentos para o estudo do Império como projeto”. In SZMERECSÁNYI, Tamás; KUZNESOF, Elizabeth Anne. "The role of merchants in the economic development of São Paulo: 1765-1850”. In Hispanic American Historical Review, v. 60, p. 571-592, nov. 1980.

LAPA, José Roberto do Amaral (Orgs). História econômica da Independência e do Império. São Paulo: Hucitec/FAPESP, 1996. p. 3-26. 
LENHARO, Alcir. As tropas da moderação: o abastecimento da Corte na formação política do Brasil: 1808-1842. Rio de Janeiro: Biblioteca Carioca, 1993.

LEONZO, Nanci. Um empresário nas milícias paulistas: o Brigadeiro Luís Antônio de Sousa. Anais do Museu Paulista, São Paulo, v. 30, p. 241-254, 1981.

LUNA, Francisco Vidal; KLEIN, Herbert S. Evolução da Sociedade e Economia Escravista de São Paulo, de 1750 a 1850. São Paulo: EDUSP, 2006.

LYRA, Maria de Lourdes Viana. Dízimos Reais na Capitania de São Paulo. Contribuição à História Tributária do Brasil Colonial (1640-1750). 1970. Dissertação (Mestrado em História) - Faculdade de Filosofia, Letras e Ciências Humanas, Universidade de São Paulo, São Paulo, 1970.

. A utopia do poderoso império: Portugal e Brasil: bastidores da política, 17981822. Rio de Janeiro: Sette Letras, 1994.

MARANHO, Milena Fernandes. A opulência relativizada: significados econômicos e sociais dos níveis de vida dos habitantes da região do Planalto de Piratininga (16481682). Bauru: Edusc, 2000.

MARCÍLIO, Maria Luiza. Crescimento demográfico e evolução agrária paulista. 1700-1836. São Paulo: Hucitec/Edusp, 2000; RABELLO, Elizabeth Darwiche. As elites na sociedade paulista da segunda metade do século XVIII. São Paulo: Safady, 1980.

. Caiçara: terra e população. Estudo de demografia histórica e da história social de Ubatuba. São Paulo: Edusp, 2006.

MARQUES, Manuel Eufrásio de Azevedo. Apontamentos históricos, geográficos, biográficos, estatísticos e noticiosos da Província de São Paulo seguidos da Cronologia dos acontecimentos mais notáveis desde a fundação da Capitania de São Vicente até o ano de 1876. São Paulo: Comissão do IV Centenário da cidade de São Paulo, 1954.

MATTOS, Renato de. Política, administração e negócios: a capitania de São Paulo e sua inserção nas relações mercantis do Império Português (1788-1808). 2009. Dissertação (Mestrado em História) - Faculdade de Filosofia, Letras e Ciências Humanas, Universidade de São Paulo, São Paulo, 2009.

MEDICCI, Ana Paula. Entre a "decadência" e o "florescimento": capitania de São Paulo na interpretação de memorialistas e autoridades públicas (1782/1822). 2005. Dissertação (Mestrado em História) - Faculdade de Filosofia, Letras e Ciências Humanas, Universidade de São Paulo, São Paulo, 2005.

- Administrando conflitos: o exercício do poder e os interesses mercantis na capitania/província de São Paulo (1765-1822). 2010. Tese (Doutorado em História) 
- Faculdade de Filosofia, Letras e Ciências Humanas, Universidade de São Paulo, São Paulo, 2010.

MONT SERRATH, Pablo Oller Mont. Dilemas e conflitos na São Paulo restaurada: formação e consolidação da agricultura exportadora (1765-1802). 2007. Dissertação (Mestrado em História) - Faculdade de Filosofia, Letras e Ciências Humanas, Universidade de São Paulo, São Paulo, 2007.

MORSE, Richard M. Formação histórica de São Paulo. São Paulo: Difusão Europeia do Livro, 1970.

MOURA, Denise A. Soares de. Sociedade movediça, economia, cultura e relações sociais em São Paulo - 1808-1850. São Paulo: Ed. Unesp, 2006.

MÜLLER, Daniel Pedro. Ensaio d'um quadro estatístico da Província de São Paulo. São Paulo: Imprensa Oficial, 1978.

NEGRÃO, Francisco. Genealogia paranaense. Curitiba: Imprensa Oficial Estado do Paraná, 1927.

NEVES, Lucia Maria Bastos Pereira das. São Paulo e a Independência. In: SILVA, Maria Beatriz Nizza da (Org.). História de São Paulo colonial. São Paulo: Ed. UNESP, 2009. p. 275-318.

OLIVEIRA, Carlos Eduardo França de. Construtores do Império, defensores da província: São Paulo e Minas Gerais na formação do estado nacional e dos poderes locais, 1823-1834. Porto Alegre: Puc-RS, 2017.

. "Estevão Ribeiro de Rezende, o Marquês de Valença: política, magistratura e construção do Estado Nacional". In Embornal. Revista eletrônica da ANPUH-CE, v. 1, p. 1-18, 2010.

OLIVEIRA, Cecilia Helena L. de Salles. A astúcia liberal. Relações de Mercado e Projetos Políticos no Rio de Janeiro (1820-1824). São Paulo: Ícone e Edusf, 1999.

. "Repercussões da revolução: delineamento do império do Brasil, 1808/1831". In GRINBERG, Keila; SALLES, Ricardo (Orgs.). O Brasil Imperial. Rio de Janeiro: Civilização Brasileira, 2009, p.17-54.

. "São Paulo e a Independência". In: CAMARGO, Ana Maria de Almeida (Org.). São Paulo, uma longa história. São Paulo: Centro de Integração Escola/ Empresa, 2004. p. 39-58. 
PAIVA, Clotilde Andrade de. População e economia nas Minas Gerais do século XIX. 1996. Tese (Doutorado em História) - Faculdade de Filosofia, Letras e Ciências Humanas, Universidade de São Paulo, São Paulo, 1996.

PERALTA, Ines Garbuio. 0 caminho do mar: subsídios para a História de Cubatão. Cubatão: Prefeitura Municipal de Cubatão, 1973.

PETRONE, Maria Thereza Schorer. A lavoura canavieira em São Paulo. Expansão e declínio (1765-1851). São Paulo, Difusão Europeia do Livro, 1968.

. 0 Barão de Iguape: um empresário na época da independência. São Paulo: Companhia Editora Nacional, 1976.

PETRONE, Pasquale. Povoamento e caminhos nos séculos XVI e XVII. In: PETRONE, Pasquale. A Baixada Santista: aspectos geográficos. São Paulo: Edusp, 1965. p. 11-73. . Aldeamentos paulistas. São Paulo: Edusp, 1995.

PRADO, Paulo. Paulística etc. São Paulo: Companhia das Letras, 2001.

PRADO JR., Caio. Evolução política do Brasil e outros estudos. São Paulo: Brasiliense, 1972.

. Formação do Brasil Contemporâneo. 34ª edição. São Paulo: Brasiliense, 1999.

PUNTSCHART, William. Negócios e negociantes paulistas (1808-1822). 1998. Tese (Doutorado em História) - Faculdade de Filosofia, Letras e Ciências Humanas, Universidade de São Paulo, São Paulo, 1998.

QUEIRÓZ, Suely Robles Reis de. São Paulo. Madrid: MAPFRE, 1992.

RICCI, Magda. Assombrações de um padre regente: Diogo Antônio Feijó (1784-1843). Campinas: Unicamp, 2001.

SÃO VICENTE, Marquês de. Marquês de São Vicente. Organização e introdução de Eduardo Kugelmas. São Paulo: Editora 34, 2002.

SOUSA, Otávio Tarquínio de. História dos fundadores do Império do Brasil. Rio de Janeiro: José Olympio Editora, 1957.

SOUZA, Iara Liz Carvalho. A pátria coroada: o Brasil como um corpo político autônomo, 1780-1831. São Paulo: Unesp, 1999.

STONE, Lawrence. "Prosopografia”. Rev. Sociol. Polit. [online]. 2011, vol.19, n.39, p.115-137. 
TAUNAY, Afonso de Escragnolle. A Câmara dos deputados sob o Império. São Paulo: Imprensa Oficial do Estado de São Paulo, 1950.

. História da cidade de São Paulo sob o Império: 1822-1831. São Paulo: Divisão do Arquivo Histórico, 1956.

VALENTIN, Agnaldo. Uma civilização do arroz: agricultura, comércio e subsistência no Vale do Ribeira (1800-1880). 2006. Dissertação (Mestrado em História) Faculdade de Filosofia, Letras e Ciências Humanas, Universidade de São Paulo, 2006.

Artigo recebido para publicação em 26/09/2020 Artigo aprovado para publicação em 29/10/2020 